DOI: 10.17117/na.2015.11.01.204

Поступила (Received): 07.11.2015

\title{
Дышекова А.А.
}

\section{Информатизация как фактор развития инновационных процессов в АПК}

\author{
Dyshekova A.A. \\ Informatization as a factor of development of innovative \\ processes in agrarian and industrial complex
}

В статье отмечается, что масштабная информатизация сферы агропромышленного комплекса позволит расширить информационное поле агроформированиям. Такой подход обеспечит принятие хозяйствующими субъектами своевременных решений в области сбыта и реализации продукции, что в перспективе снизит финансовые ограничения для доступа к инновационным технологиям

Ключевые слова: информатизация агросферы, инновационный процесс, структурно-

технологическая модернизация АПК

\section{Дышекова Альбина Аскерхановна}

Кандидат экономических наук, доцент

Кабардино-Балкарский государственный аграрный университет им. В.М. Кокова

2. Нальчик, ул. Ленина, 1 В

\begin{abstract}
The article notes that large-scale Informatization of the sphere of agro-industrial complex will expand the information field of the agricultural companies. This approach will ensure adoption of economic entities timely decisions in the field of marketing and sales, which will reduce financial constraints for access to innovative technologies
\end{abstract}

Key words: informatization of agricultural, innovation process, structural and technological modernization of agriculture

\author{
Dyshekova Albina Astarhanova \\ Candidate of Economic Sciences, Associate Professor \\ Kabardino-Balkarian state agrarian university \\ named V.M. Kokov \\ Nalchik, Lenin st., 1 B
}

Инновационный путь развития АПК связан со структурно-технологической перестройкой комплекса, что, в свою очередь предполагает, модернизацию системы управления во всех аспектах его функционирования, с внедрением новых технологий и повышением квалификации кадров. Первым этапом в решении этой проблемы должна стать масштабная информатизация агросферы, включающая создание и внедрение новейших средств вычислительной техники в производственную, социальную, организационно-экономическую и научную сферы сельского хозяйства и перерабатывающей промышленности с целью получения конкурентной продукции при максимально эффективном использовании интеллектуальных, трудовых, материальных, финансовых и природных ресурсов. Реализация указанного этапа расширит информационное поле принятия решений хозяйствующими субъектами в сбыте продукции и ее поставках, в перспективе снизит финансовые ограничения для доступа к инновационным 
технологиям. Необходимость нацеленности государственных программных механизмов развития АПК на поддержку этих процессов и формирование значимых инновационных стимулов у хозяйствующих субъектов самоочевидна. Система управления процессами структурно-технологической модернизации АПК, таким образом, включает два уровня, на первом из которых усилиями регулирующих органов создаются условиях для предполагаемых структурных и технологических изменений, формируются стимулы для соответствующих преобразований на микроуровне. Субъекты же последнего на втором уровне указанной системы реализуют накопленные стимулы, активно вовлекаясь в перестроечный, по сути своей инновационный процесс.

Конкретным целям информатизации АПК служат повышение качества управления с переводом на экономические методы хозяйствования, повышение оперативности в управлении производством и сбытом готовой продукции, значительного повышения ее качества и достижения конкурентной способности на международном рынке, внедрение ресурсосберегающих и безотходных технологий, ускорение научных исследований; проектирование и внедрение достижений науки и техники в производственной деятельности АПК $[2,4]$.

Процесс информатизации АПК представляет собой создание и внедрение новейших средств вычислительной техники в производственную, социальную, организационно-экономическую и научную сферы сельского хозяйства и перерабатывающей промышленности с целью получения конкурентной продукции при максимально эффективном использовании интеллектуальных, трудовых, материальных, финансовых и природных ресурсов $[3,5]$.

Информатизация АПК должна реализовываться по следующим направлениям:

- встраивание микропроцессорных устройств в машины и оборудование;

- автоматизация производственных и технологических процессов;

- информатизация организационно-экономических процессов;

- информатизация процессов научного обслуживания предприятий АПК, отрасли, региона;

- обучение компьютерной грамотности при подготовке и переподготовке кадров;

- создание комплексно-автоматизированных систем управления АПК в целом.

На современном этапе развития информатизации АПК представлена двумя направлениями: экономико-организационными системами, созданными на базе вычислительных центров или отделов (лабораторий) по обработке информации и автоматизированными системами управления технологическими процессами (в основном в перерабатывающей промышленности) $[1,6]$.

Информатизация АПК должна обеспечить:

- применение новых актуальных экономических методов управления;

- улучшение качества и повышение производительности труда;

- переход на безбумажные технологии посредством автоматизации делопроизводственных функций; 
- ускорение процессов внедрения нововведений по всем направлениям функционирования предприятий;

- решение проблем села, уровня грамотности и благосостояния жителей села;

Указанные цели в АПК должны достигаться за счет создания Единой системы информационно-вычислительного обеспечения системы АПК как сети интегрированных систем управления отраслями и едиными для всего АПК функциями управления, объединяющими весь жизненный цикл создания конечных продуктов в производстве, оперативность и качество принимаемых решений в управлении, максимальное повышение интеллектуальных данных в науке, расширение и повышение качества услуг населению в быту и на работе. Единая система информационно-вычислительного обеспечения АПК представляет собой интегрированную многоотраслевую и многоуровневую систему управления предприятиями аграрного сектора. Она должна обеспечивать формирование единой базы данных отраслевой, межотраслевой и региональной информации, обмен информацией между сферами и предприятиями АПК и способствовать решению совместимых задач в различных отраслях аграрного сектора.

\section{Список используемых источников:}

1. Аброкова Л.С. Государственные программы поддержки и развития АПК // Актуальные проблемы науки в современной России. Ростов-на-Дону, 2014. С. 74-77.

2. Аброкова Л.С. Проблемы государственного регулирования процессов распределения и использования доходов бюджета в РФ // Совершенствование налогообложения как фактор экономического роста. 2014. C. 21-25.

3. Казова 3.М. Методика оценки эффективности управления межбюджетными отношениями на субфедеральном уровне // Инновационная экономика: перспективы развития и совершенствования. 2014. № 1 (4). C. 258-262.

4. Казова З.М. Федеральная политика межбюджетных отношений и направления ее совершенствования // Инновационная экономика: перспективы развития и совершенствования. 2014. № 1 (4). C. 262-267.

5. Кулова Л.С. Формирование механизма управления конечными результатами функционирования субъектов АПК (на материалах кабардино-балкарской республики) диссертация на соискание ученой степени кандидата экономических наук. Нальчик, 2004.

6. Фиапшев А.Б. Формирование социально-экономической концепции функционирования и развития региона. Автореферат диссертации на соискание ученой степени кандидата экономических наук. Москва, 1994.

(C) 2015, Дышекова А.A.

Информатизация как фактор развития инновационных процессов в АПК
(C) 2015, Dyshekova A.A. Informatization as a factor of development of innovative processes in agrarian and industrial complex 